\title{
Reconstruction of Large Anterior Palatal Fistulae Using Tongue Flaps
}

\section{Geniş Anterior Palatal Fistüllerin Dil Flepleri Ile Rekonstrüksiyonu}

Naouar Ibnouelghazi ${ }^{1}$,

Zakaria Aziz ${ }^{1}$

Jinane Kharbouch ${ }^{1}$,

Salma Aboulouidad ${ }^{1}$,

Nadia Mansouri-Hattab ${ }^{1}$

'Oral, Maxillo-facial and Aesthetic Surgery Department, Mohammed VI University Hospital, Marrakesh School of Medicine, Cadi Ayyad University, Morocco

Geliş Tarihi/Received: 25 February 2020 Kabul Tarihi/Accepted: 9 May 2020

Address correspondence to: Naouar Ibnouelghazi, Oral, Maxillo-facial and Aesthetic Surgery Department, Mohammed VI University Hospital, Marrakesh School of Medicine, Cadi Ayyad University, Morocco e-mail: ibnounawar@gmail.com

\section{ORCID}

Naouar Ibnouelghazi

https://orcid.org/0000-0002-7250-9127

Zakaria Aziz

https://orcid.org/0000-0001-5382-2372

Jinane Kharbouch

https://orcid.org/0000-0002-7871-8755

Salma Aboulouidad

https://orcid.org/0000-0002-4588-1353

Nadia Mansouri-Hattab

https://orcid.org/0000-0002-5764-2851

\begin{abstract}
Öz
Amaç: Dil, yarık damak fistüllerinin kapatılması için en uygun donör bölgesidir. Bu prospektif çalışmanın amacı, dil flep tekniğinin etkinliğini yeniden değerlendirmekti.

Hastalar ve Yöntem: 2015-2017 yılları arasında anterior tabanlı dil flebi ile rekonstrüksiyon yapılan 4 yarık hasta incelendi. Flebin fistülü kapatma yeteneği, ameliyattan en az 1 yıl sonra kalan dil şekli ve konuşma gelişimi (hastanın öz değerlendirmesi ve ebeveynlerin görüşü) gibi değişkenler değerlendirildi. Bulgular: Tip IV palatal fistül ve bir tip V ile başvuran 4 hastanın damak fistülleri dil flebi ile çift katmanlı şekilde kapatıldı. Hastaların ortalama yaşı 68,5 idi. Illk malformasyon 2 hastada tek tarafı komple damak yarığı ve diğer 2 hastada damak velar yarıktı. Fistüllerin boyutu 7 ila $12 \mathrm{~mm}$ arasında değişmekteydi. Ortalama 18 aylık takip süresinde hastaların tamamında dil estetiği ve fonksiyonunda tam iyileşme görülürken, fistül nüksü olmadı.

Sonuç: Dil flepleri, mükemmel vaskülariteleri nedeniyle yarık damak cerrahisinde kullanılır ve sağladıkları büyük miktarda doku, dil fleplerini, önceki cerrahi tarafından yaralanan damaklardaki büyük fistüllerin onarımı için özellikle uygun hale getirmiştir. Palatal fistüllerin kapatılması için bunu güvenilir bir cerrahi teknik olarak öneriyoruz.
\end{abstract}

Anahtar Kelimeler: Miyotonik distrofi, kardiyak bulgu, presenkop

\section{Abstract}

Aim: The tongue is a most suitable donor site for the closure of cleft palate fistulae. The aim of this prospective study was to reassess the efficacy of tongue flap technique.

Patients and Methods: 4 cleft patients who underwent reconstruction by anteriorly based tongue flap between 2015 and 2017 were studied. Variables such as flap's ability to close the fistula, the remaining tongue shape at least 1 year after surgery, and speech improvement (patient's self-assessment and parents' opinion) were evaluated.

Results: 4 cases presenting with type IV palatal fistulae and one type $V$ were operated on using a doublelayer closure with tongue flap. The average age at the time of the intervention was 68,5 years. The initial malformation was a complete unilateral cleft for 2 patients, and a palate velar cleft for the 2 others. The size of the fistulas was variable in length $(7$ to $12 \mathrm{~mm})$. The procedure was successful as no recurrence of fistula was noticed at an average follow-up of 18 months, with full recovery of tongue esthetic and function.

Conclusion: Tongue flaps are used in cleft palate surgery because of their excellent vascularity, and the large amount of tissue that they provide has made tongue flaps particularly appropriate for the repair of large fistulas in palates scarred by previous surgery. We recommend this as a reliable surgical technique for the closure of palatal fistulas.

Key words: Myotonic dystrophy; cardiac manifestation; presyncope

\section{INTRODUCTION}

Palatal fistulas represent an important concern in the treatment of cleft palates (1). The first reference to the use of the tongue to close palatal fistulae after cleft palate repair is the paper by Guerrero-Santos and Altamirano (1966) (2). Anatomically, the tongue has a rich vascular supply. This is predominantly from the lingual artery which branches into the dorsal lingual, deep lingual and sublingual arteries. It also has a secondary supply from the tonsillarbranch of the facial artery and the ascending pharyngeal artery. Consequently, the blood supply is abundant with a rich submucous plexus of vessels on the dorsum of the tongue that provides an excellent site to raise either a dorsal or anterior-based flap (3). There are many methods proposed for closure of palatal defects.

Large defects present a more difficult problem. The aim of this paper is to report our experience with
Cite this article as: Ibnouelghazi N, Aziz Z, Kharbouch J, Aboulouidad S Mansouri-Hattab N. Reconstruction of Large Anterior Palatal Fistulae Using Tongue Flaps. Selcuk Med J 2020;36(2): 138-142 Disclosure: None of the authors has a financial interest in any of the
products, devices, or drugs mentioned in this article. The research was
not sponsored by an outside organization. All authors have agreed to allow
full access to the primary data and to allow the journal to review the data
if requested. 
the use of tongue flaps for the repair of large palatal defects in adult cleft patients. A number of fistulae can be closed with local tissue using turnover flaps based on a margin of the defect to provide nasal layer cover. Almost always these flaps must be based on a scar at the margin of the defect and their blood supply is, therefore, necessarily somewhat precarious.

Oral layer cover can often be provided by transposition flaps from local palatal tissue or, in the presence of a complete cleft, by buccal sulcus flaps introduced into anterior hard palate defects through the alveolar defect. However the introduction of a tongue flap with its bulk of vascular soft tissue now makes it possible to close fistulae previously
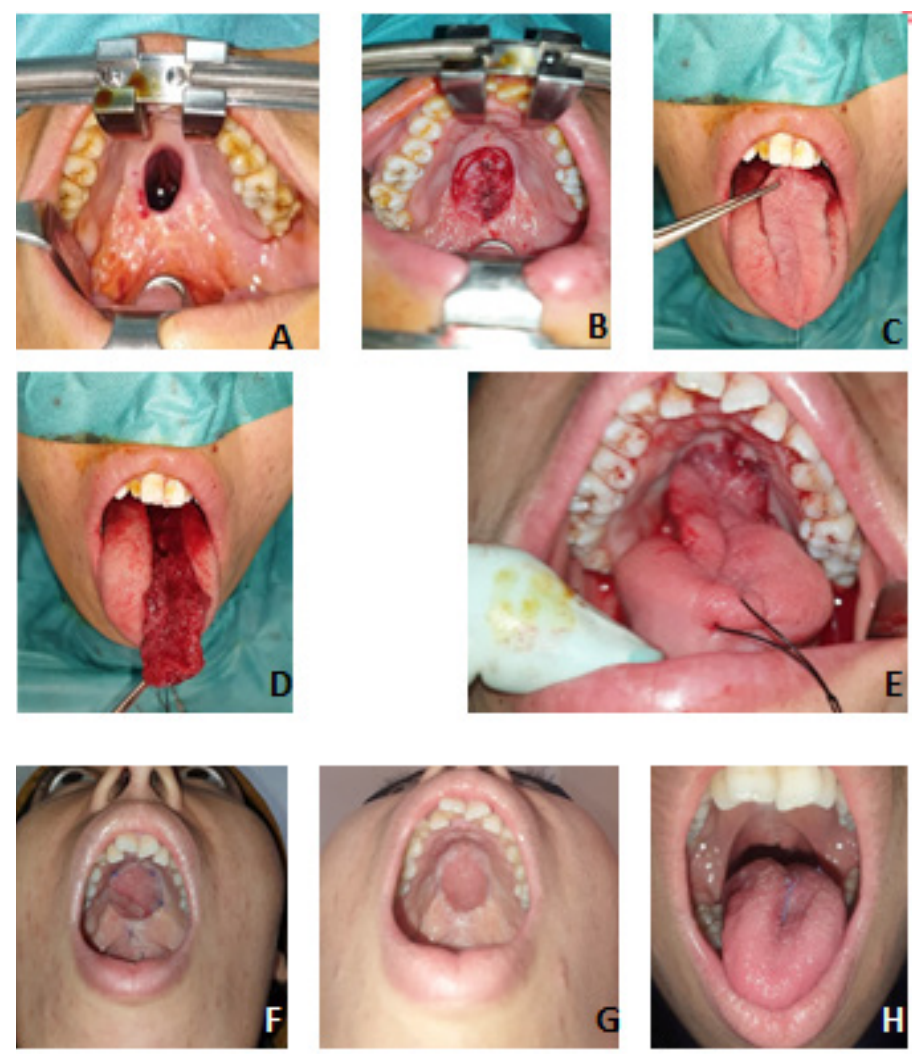

Figure 1. A. hard palatal fistula; B. closure of the nasal layer. C. tongue flap with an anteriorly based pedicle; D. Anteriorly based tongue flap is raised; E. the donor site is sutured sutures till lower edge of raised flap. And the tongue flap was then rotated forward and sutured to the raw edges of the palatal defect anteriorly and laterally. F. After 21 days, the flap is divided and set into the posterior aspect of the palatal defect; G. Result 6 months following fistula closure; H. Donor site defect closed considered inoperable. It is a last chance option. The indications for closing palatal fistulae include: The embarrassment of fluids leaking down the nose and to a lesser extent, rhinitis and catarrh produced by food lodging in the nose. Interference with articulation. This feature is not uncommon in those patients who develop a habit of closing the fistula with part of their tongue. In other patients audible nasal escape and hypernasal resonance can mar the quality and reduce the volume and continuity of speech.

We used the Pittsburgh Fistula Classification System includes seven fistula types (Figure. 1). Fistulas at the uvula, or bifid uvula, are considered a type I fistula. Type II fistulas occur within the soft palate. Type III fistulas are found at the junction of the soft and hard palates. Type IV fistulas are located within the hard palate. Type $\vee$ fistulas are defined as fistulas at the incisive foramen (junction of the primary and secondary palates) in the context of Veau IV clefts. Type VI fistulas are lingual- alveolar, and type VII fistulas are labial-alveolar fistulas. In this study, we limited ourselves to fistulas located within the hard palate Type IV and the junction primary/secondary palate Type V.

\section{PATIENTS AND METHODS}

4 cleft patients who underwent reconstruction by anteriorly based tongue flap between 2015 and 2017 were studied. Variables such as flap's ability to close the fistula, the remaining tongue shape at least 1 year after surgery, and speech improvement (patient's selfassessment and parents' opinion) were evaluated.

The surgical procedure was as follows:

\section{First operational time}

\subsection{Installation}

The procedure was conducted under general anesthesia with nasotracheal intubation; the patient was placed in a dorsal position with the head resting on a headrest. After disinfection of the oral cavity with polyvidone iodine, the loss of substance from the palate is measured with a graduated ruler. The tongue was then maintained outside the oral cavity by suture in the apex of tongue, maintaining its symmetry, so that the incision traces could be drawn. Incision was performed around the fistulous tract to design a local flap for nasal closure ; mucosalized edges were excised. The nasal layer was identified and carefully dissected then inversed margins are sutured without tension using 4-0 Vicryl.

\subsection{Raising the anterior-based tongue flap}

The flap is delineated with a marking pen. The cleft 
length dictates its length, and the flap should sit passively. The width should be slightly greater than the cleft defect and the depth of the flap should be approximately $3 \mathrm{~mm}$, to include intrinsic muscle, which may deepen to $5 \mathrm{~mm}$ toward the base. Up to $2 / 3$ of the dorsal surface may be used without significant tongue deformity. Care must be taken not to extend the flap too close to the circumvallate papillae or the tip of the tongue. Adequate hemostasis is maintained throughout with bipolar diathermy. The donor site is closed with 4.0 resorbable suture taking care not to constrict the pedicle base. The flap is positioned within the defect. It is sutured into the reception site with a 4.0 resorbable suture, anteriorly and laterally. Nasogastric tube was placed to assist in feeding.

\section{Second operational time}

After 15 days to 21 days, the patient was taken back into the operation theater; under local anesthesia, the flap was divided and set into the posterior aspect of the palatal defect

The donor site defect was closed using 4-0 Vicryl.

Patients were assessed under the following criteria at 1 week, 1 month, 3 months, 6 months, and thereafter at 1-year intervals: (1) flap viability; (2) fistula closure; (3) residual tongue function and aesthetics; (4) assessment of speech impediment. Length of follow-up period ranged from 2 weeks to 18 months, with an average length of 15 month.

\section{Postoperative care}

Feeding is via a nasogastric tube between two operating times, to facilitate the cicatrization. Oral hygiene must be rigorous and include baths of mouth of an iodine solution. A few days after the second operative time, the nasogastric tube is removed. The food is then mixed until the palate is healed.

\section{RESULTS}

4 cases were operated on using a double-layer closure with tongue flap (Table 1). Most of the fistulas reviewed were of Type IV as per the Pittsburgh
Fistula Classification System (1). The success rate of these 4 cases was $100 \%$, with no recurrence of fistula at an average follow-up of 18 months. The study was prospective, on 4 patients. They had a type IV secondary palate fistula. The average age at the time of the intervention was 68,5 years. The initial malformation was a complete unilateral cleft for 2 patients, and a palate velar cleft for the 2 others. The size of the fistulas was variable in length (7 to $12 \mathrm{~mm}$ ), but never exceeded $1 \mathrm{~cm}$ in width. The history of attempted closures ranged from 1 to 3 . The procedure was well tolerated by our patients, and our outcomes demonstrate excellent healing both short and long term. None of our patients had premature flap dehiscence or necrosis and there were no complications at the tongue donor site. There have been no problems with tongue function postoperatively, and patients have reported no problems with feeding. There have been no palatal fistulae reported.

Speech was reported to have improved, but this will be assessed more formally. Table 2 shows patient's satisfaction towards Tongue's function and esthetic and speech improvement. The tongue flap is simple and reliable for the reconstruction of relatively extensive palatal defects. It has the advantage of preserving the function and aesthetics of the donor site and the recipient site. Primary treatment of cleft palate should result in an intact palate with separation of the oral and nasal cavities. However, the published reports of large series indicate fistula can recur in the secondary palate of a small but significant group of patients; the incidence varies from $8.9 \%$ to $34 \%$ (4). Fistulas may occur in the labial vestibule, the alveolus, the hard palate, and at the junction between the hard and soft palate. Symptoms of these fistulas may be hypernasality in speech, regurgitation of fluids into the nose, and food lodging in the defect. The symptoms depend to some extent on the site of the fistula.

In accordance with literature, most of the fistulas were located in anterior palate. In our study, The

Table 1. Demographic Data of the Patients

\begin{tabular}{lllllll}
\hline Age $(\mathbf{y r})$ & Gender & $\begin{array}{l}\text { Number of } \\
\text { Prior } \\
\text { Closures }\end{array}$ & Size (cm) & Type & $\begin{array}{l}\text { Flap } \\
\text { Orientation }\end{array}$ & $\begin{array}{c}\text { Follow } \\
\text {-up }\end{array}$ \\
\hline Case 1 & 13 & Male & 2 & $10 \mathrm{~mm}$ & IV & Anteriorly based \\
-ation
\end{tabular}


Table 2. Patients evaluation of speech improvement and tongue function

\begin{tabular}{|c|c|c|c|c|c|c|c|}
\hline \multicolumn{2}{|c|}{$\begin{array}{l}\text { Preservation of } \\
\text { Tongue mobility } \\
\text { function }\end{array}$} & \multicolumn{2}{|c|}{$\begin{array}{l}\text { Preservation of } \\
\text { Tongue sensatory }\end{array}$} & \multicolumn{2}{|c|}{$\begin{array}{l}\text { Preservation of } \\
\text { Tongue esthetic }\end{array}$} & \multicolumn{2}{|c|}{ Speech improvement } \\
\hline Yes & No & Yes & No & Yes & No & None & Yes \\
\hline $100 \%$ & $0 \%$ & $100 \%$ & $0 \%$ & $100 \%$ & $0 \%$ & $0 \%$ & $100 \%$ \\
\hline
\end{tabular}

Pittsburgh Fistula Classification System was used to describe fistula. Most of the fistulas located within the hard palate Type IV (1). Attempts at closure using only local transposition flaps may be successful, although frequently this is not achieved and a smaller oronasal fistula will recur. Additional attempts to gain closure with local tissue alone often result in repeated failure as thick and immobile scarred palatal mucoperiosteum leads to closure under tension with subsequent flap necrosis and wound dehiscence. A variety of both surgical and prosthetic solutions to the problem of inadequate local tissue have been sought. The FAMM (facial artery musculomucosal) flap as introduced by Pribaz et al is a valuable option to reconstruct moderate-size defects of the anterior palate. The FAMM flap has few minor drawbacks;
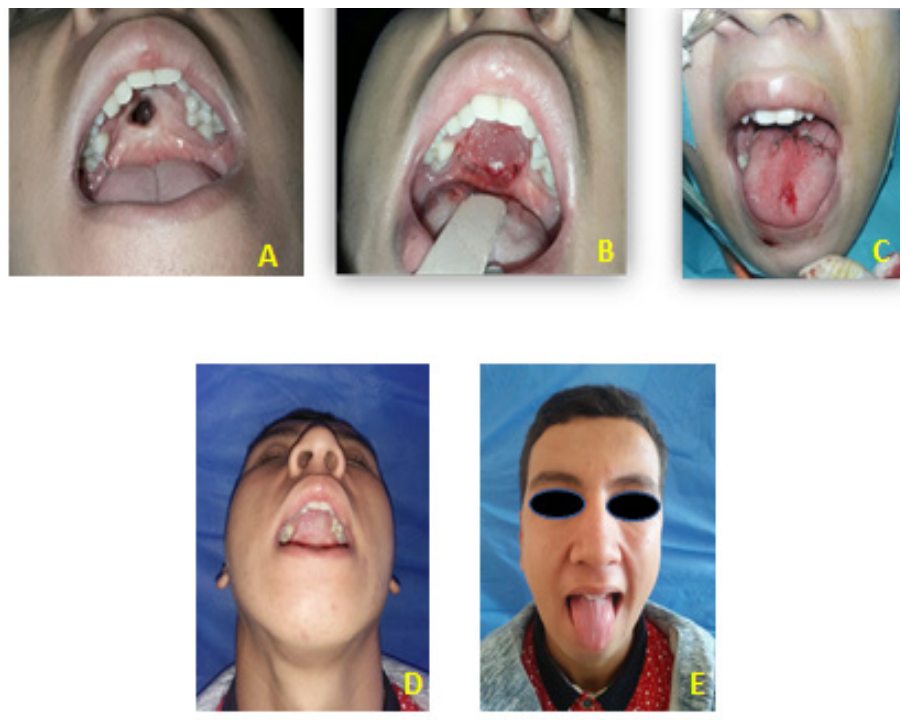

Figure 2. (Case 1). A. Preoperative palatal fistula; B. Fistula complete closure after 21 days postoperatively; C. Shape of tongue after tongue flap pedicle devision; D. Result 8 month after palatal fistula closure using anteriorly based tongue flap; E. Preservation of tongue esthetic at 8 months postoperatively first, the pedicle may be injured during mastication to the point that the pedicle gets severed (5). And speech therapists discourage the use of a flap that, with the inclusion of facial muscles, will likely interfere with further speech development. Tongue flaps have been used to close intraoral defects following tumor surgery, severe infection, trauma, and cleft palate fistulas. According to De Santo, tongue flaps are also useful after radiation therapy. Posteriorly based flaps are indicated when treating defects of soft palate, retromolar region, floor of the mouth, and posterior buccal mucosa.

Anteriorly based flaps are useful in the treatment of defects of the hard palate, anterior buccal mucosa, lips, and anterior floor of the mouth. Pigott et al (2) presented their work on 20 patients with palatal fistulas, which were successfully closed with tongue flaps in 17 patients (85\%). Contreras et al used tongue flap and forehead flap for closure of residual oronasal fistula, and they concluded that when all other surgical possibilities have failed, tongue, vestibular mucosa, pharynx, or forehead flap can be used to restore mucosal continuity (8). The authors concluded that the anteriorly based dorsal tongue flap is a safe and effective method for closure of relatively large palatal defects. The parameters for success include sufficient length of the flap (5 to $6 \mathrm{~cm}$ ), a flap width somewhat larger than the defect, and a flap thickness of $0.5 \mathrm{~cm}$ (7). Alsalman et al. (15) used the single-layer closure for closing a palatal fistula.

Many surgeons have emphasized a double-layer closure for closing a palatal fistula to ensure nonrecurrence (4, 9-11); some surgeons have introduced a 3-layer closure arguing better outcomes $(12,13)$ Some surgeons choose to limit the movement of the tongue to ensure better healing by fixing or anchoring the tongue flap to the nasal septum. Others choose more radical options like intermaxillary fixation or button suture to the lip, which makes the procedure more uncomfortable to the patients and limits the possibility of feeding (14). This was not done in any of our patients. Too much of the tongue movement is automatically restricted because of the pain 
associated with it. Mahajan et al. (15) reported a series of 41 cases, where they used tongue flaps for closure of palatal fistula with no additional fixation of the flap. Many surgeons have emphasized a doublelayer closure for closing a palatal fistula to ensure non-recurrence. $(4,9,10)$. Alsalman et al $(16)$ used a modified single layer closure with tongue flap in cleft patients. In addition, some surgeons have introduced a 3-layer closure, arguing better outcomes. $(12,13)$ In small fistulas, the nasal layer closure can be achieved by direct closure of the nasal layer or mobilizing some of the nasal mucosa.2,3

However, in large fistulas or excessively scarred palatal nasal layer, it is difficult to achieve closure in most cases. Therefore, a more robust flap, such as buccal flap, pharyngeal flap, or inferior turbinate flap, may be needed to close the nasal layer. We prefer to close the nasal layer using 2-layered reconstructions. Flap division has been done by various authors varying from 10 to 21 days $(9,17)$. In our series, we chose to do flap division after a period of 3-week. The tongue flap when compared to other reconstructive options has the advantage of an abundant vascular structure with significantly decreased rates of fistula recurrence after surgery. The second advantage of dorsal tongue flaps is the ease of planning the flap in sufficient length, width, and depth needed for the location and dimension of the fistula. The tongue flap has the advantage of giving a good volume by adding muscular tissue.

\section{CONCLUSION}

The Tongue flap is a reliable option to close a complicated palatal fistula. The study justifies the use of tongue flap for closure of palatal fistulas, as it provides abundant tissue with esthetic morbidity of the donor site. Hence, we would recommend this as a reliable surgical technique for the closure of palatal fistulas.

Conflict of interest: Authors declare that there is no conflict of interest between the authors of the article.

Financial conflict of interest: Authors declare that they did not receive any financial support in this study.

Address correspondence to: Naouar Ibnouelghazi, Oral, Maxillo-facial and Aesthetic Surgery Department, Mohammed VI University Hospital, Marrakesh School of Medicine, Cadi Ayyad University, Morocco

e-mail: ibnounawar@gmail.com

\section{REFERENCES}

1. Smith DM, Vecchione $L$, Jiang $S$, et al. The Pittsburgh fistula classification system: A standardized scheme for the description of palatal fistulas. Cleft Palate Craniofac J 2007;44:590-4.

2. Pigott RW, Rieger FW, Moodie AF. Tongue flap repair of cleft palate fistulae. Br J Plast Surg 1984;37:285-93.

3. Vig $\mathrm{N}$, Ujam $\mathrm{A}$, Elburi $\mathrm{H}$. The use of tongue flaps in primary cleft palate repair. J Cleft Lip Palate Craniofac Anomal 2017;4, Suppl S1:78-83

4. Vasishta SM, Krishnan G, Rai YS, et al. The versatility of the tongue flap in the closure of palatal fistula. Craniomaxillofac Trauma Reconstr 2012;5:145-60.

5. Pribaz J, Stephens W, Crespo L, et al. A new intraoral flap: Facial artery musculomucosal (FAMM) flap. Plast Reconstr Surg 1992;90:421-9.

6. Johnson PA, Banks P, Brown AE. Use of the posteriorly based lateral tongue flap in the repair of palate fistulae. Int $\mathrm{J}$ Oral Maxillofac Surg 1992;21:6-9.

7. Busić N, Bagatin M, Borić V. Tongue flaps in repair of large palatal defects. Int J Oral Maxillofac Surg 1989;18(5):291-3.

8. Contreras O, Gonzales M, Villalobos RA. The tongue and forehead flap in the closure of residual oronasal fistulae. $J$ Craniomaxillofac Surg 1989;17(Suppl 1):39-41.

9. Sadhu P. Oronasal fistula in cleft palate surgery. Indian $\mathrm{J}$ Plast Surg 2009;42 Suppl:S123-28. 3.

10. Sodhi SP, Kapoor P, Kapoor D. Closure of anterior palatal fistula by tongue flap: A prospective study. J Maxillofac Oral Surg 2014;13:546-9.

11. Diah E, Lo LJ, Yun C, et al. Cleft oronasal fistula: A review of treatment results and a surgical management algorithm proposal. Chang Gung Med J 2007;30:529-37.

12. Murrell GL, Requena R, Karakla DW. Oronasal fistula repair with three layers. Plast Reconstr Surg 2001;107:143-7.

13. Tuncbilek G, Konas E, Kayikcioglu A, et al. Three-layer oronasal fistula repair with sandwiched mastoid fascia graft. J Craniofac Surg 2012;23(3):780-3.

14. Steinhauser EW. Experience with dorsal tongue flaps for closure of defects of the hard palate. J Oral Maxillofac Surg 1982;40:787-9.

15. Mahajan RK, Chhajlani R, Ghildiyal HC. Role of tongue flap in palatal fistula repair: A series of 41 cases. Indian J Plast Surg 2014;47:210-5.

16. Alsalman, Abdulla K. Single-layer closure with tongue flap for palatal fistula. Plast Reconstr Surg Glob Open 2016;4:e852.

17. Murthy J. Descriptive study of management of palatal fistula in one hundred and ninety-four cleft individuals. Indian J Plast Surg 2011;44:41-6. 